\title{
MEB 2012 Güzel Sanatlar ve Spor Liseleri Drama Dersi Öğretim Programının Değerlendirilmesi
}

\author{
Doç. Dr. Ömer ADIGÜZEL ${ }^{1}$
}

\begin{abstract}
$\ddot{O}_{z e t}$
Bu çalışma, Milli Ĕgitim Bakanlı̆̆ Güzel Sanatlar ve Spor Liseleri Drama Dersi Öğretim Programı'nın değerlendirilmesini amaçlamaktadır. Drama dersine ilişkin olarak geliştirilen ögretim programı dokümanları taranmış ve elde edilen veriler, doküman analizi ile incelenmiştir. Çalışmada, Milli Ĕ̆itim Bakanlı̆̆ Ortaöğretim Genel Müdürlügü tarafindan hazırlanan ve Talim Terbiye Kurulu tarafindan 05.04.2012 tarih ve 20. sayl ile onaylanan "Güzel Sanatlar ve Spor Liseleri Drama Dersi Öğretim Programı”, öğretim programı ögeleri (amaç, içerik, ilkeler, programda önerilen yöntem teknik, araç-gereç ve öğrenme-ögrretme süreci) kategorileri bağlamında, yaratıcı drama alan bilgisi, amaçları, özellikleri ve ilkelerine uygunluğu açısından değerlendirilmiştir. Araştırma sonucunda, programın model çalışma yapılmadan, alan uzmanları ve ilgili sivil toplum örgütlerinden görüş alınmadan, eğitim ihtiyacı ve drama eğitim içeriği tam saptanmadan ve uluslararası örneklerden yararlanılmadan hazırlandı̆̆ı belirlenmiştir. 2012 Drama Dersi Öğretim Programı'nın 2006 yılında uygulanan programın bir tür "yenilenmiş" hâli olmasına karşın bir program değerlendirme sürecine tabi tutulmadiğı görülmüş̧ür. Programda kuramsal bilgiler açısından önemli eksiklik ve yanlışlıklar saptanmış, programın genel amaçları ile ünite başlık ve kazanımlarının tutarlı olmadığı, ögrenme-öğretme süreçleri açısından ders planlartnın dramanın özellik ve ilkelerine uygun olarak hazırlanmadığı ve bu haliyle uygulanmasının olanaksız olacağı sonucuna ulaşılmıştır.
\end{abstract}

Anahtar Sözcükler: Milli Ĕ̆itim Bakanlı̆ğ Güzel Sanatlar ve Spor Liseleri Drama Dersi Öğretim Programi, Yaratıcı Drama, Drama Dersi.

\section{Assessment of Ministry of Education 2012 Fine Art and Sports High School Drama Lecture Teaching Program}

\begin{abstract}
This study is aimed at assessing the teaching program of the Fine Arts of Ministry of Education and Sport High School Drama lecture. Documents of teaching program developed in relation to Drama lecture were searched and the data obtained was analyzed by document analysis. In this study, "Fine Arts and Sport High School Drama lecture Teaching Program" which was prepared by General Management of Ministry of Education and approved by Board of Education and Discipline with date 05.04.2012 and number 20 were assesed by considering teaching program components (purpose, content, principles, methods, techniques, instruments and teaching-learning process suggested in the program) in terms of relevance to creative drama field knowledge, purposes, properties and principles. At the end of the study, it was determined that the program was prepared without carrying out any model study, without getting opinons of field experts, without establishing educational need and drama education program. Although 2012 Drama lecture teaching program was a modified version of the program applied in 2006, it was seen that it did not include any assessment process. Important deficiencies and errors were detected in theoretical information of the program and it was concluded that general purposes of the program was not consistent with the title of the units and also objectives and lesson plans were not prepared by considering properties and principles of drama and so it is not possible for the valid program to be applied in schools.
\end{abstract}

1 Ankara Üniversitesi Eğitim Bilimleri Fakültesi Öğretim Üyesi (omeradiguzel@gmail.com) 


\section{Giriş}

Bir eğitim programı, amaç, içerik, öğrenme-öğretme süreci ve değerlendirme gibi ögelerden oluşmaktadır. Eğitim programında bu ögelerin birbirlerini destekler, birbirleriyle ilişkili ve birbirine sıkı sıkıya bağlı olması gerekir. Bu yönüyle programın bir ögesinde yapılacak değişiklik, programın tümünü etkilemektedir. Bu açıdan bakıldığında eğitim programlarının dinamik bir süreç olduğu ve değerlendirmeler 1şığında sürekli olarak geliştirilmesi gerekmektedir. Eğitim programları geliştirilirken de programa bilimsel bir bakış açısıyla bakılması ve programın eğitim programları hazırlama ilkelerinin göz önüne alınarak hazırlanması oldukça önemlidir. Ayrıca eğitim programlarının gerekli ön çalışmalar yapılmadan hazırlanması ve uygulamaya konulması, bir programın etkililiği için yeterli olmadığı gibi programın başarısını da önemli ölçüde etkileyebilmektedir. Bu nedenle, uygulama sürecinden gelen dönütlere dayalı olarak programın sürekli olarak değerlendirilmesi ve geliştirilmesi gerekmektedir.

Milli Eğitim Bakanlığı tarafından “Drama Dersi” adıyla bugüne kadar biri Çerçeve Program olmak üzere üç program hazırlanmış ve uygulanmıştır. Bu programlardan ilki “İlköğretim Okulları Seçmeli Drama Dersi 1-2-3 Öğretim Programı'dır. Buna göre drama dersinin seçimlik olarak ilköğretim 4.sınıftan 8. sınıfa kadar haftada 1-2 ders saati biçiminde uygulanması öngörülmüştür. Bu program ilkokulların dört yıla indirilmesinden sonra ortaokul 5. ve 6. sınıflarda okutulmaya çalışılan ve 2012 yılında hazırlanan Ortaokul ve İmam Hatip Ortaokulu Drama Dersi (5 ve 6. Sinıflar) Öğretim Programı'na kadar uygulanmıştır.

İkinci program, Milli Eğitim Bakanlığı Ortaöğretim Genel Müdürlüğü tarafından 2006 yılında hazırlanan ve 2008 yılında da 9. sınıflar için yenilenen Anadolu Güzel Sanatlar Lisesi Drama Dersi Öğretim Programı'dır (MEB; 2008). Bu program da 2012 yılına kadar ortaöğretim programlarında seçimlik ders olarak okutulmuş ve 05.04.2012 tarih ve 20 sayılı kararı ile "aynı" program temel alınarak hazırlanan Güzel Sanatlar ve Spor Liseleri Drama Dersi Öğretim Programı'na (MEB; 2012) kadar uygulanmıştır.

Bu çalışma MEB 2012 Drama Dersi Öğretim Programı'nı, eğitim programının ögeleri ve yaratıcı drama alanın özellikleri doğrultusunda değerlendirmeyi amaçlamaktadır. Bu amaca ulaşmak için aşağıdaki sorulara yanıt aranmıştır.

1. Drama Dersi Öğretim Programı, program geliştirme ilkeleri açısından uygun mudur?

2. Drama Dersi Öğretim Programı'nda yer alan kuramsal bilgiler, dramanın alan bilgisi, amaçları ve özellikleri ile tutarlı midır?

3. Drama Dersi Öğretim Programı'na göre dersin yapılandırması, drama sürecine uygun mudur?

4. Drama Dersi Öğretim Programı'nın yapısını oluşturan ögeler (amaç, beceriler, değerler, üniteler, etkinlikler), drama öğretimi açısından uygun ve birbirleri ile tutarlı mıdır?

\section{Yöntem}

Drama Dersi Öğretim Programı'nın değerlendirilmesini amaçlayan bu araştırma, tarama modeline dayalı, nitel veri toplama araçlarının kullanıldığı ve algıların gerçekçi ve bütüncül bir biçimde ortaya konmasını amaçlayan nitel bir araştırmadır (Yıldırım ve Şimşek, 2011: 39). Araştırma kapsamında drama dersine ilişkin olarak geliştirilen öğretim programları taranmış ve elde edilen veriler, doküman incelemesi ile yaratıcı drama alan bilgisi, amaçları, özellikleri ve ilkelerine uygunluğu açısından analiz edilmiştir. Doküman incelemesi, araştırılması hedeflenen olgu veya olgular hakkında bilgi içeren yazılı materyallerin analizini kapsar (Yıldırım ve Şimşek, 2011: 187). Bu bağlamda, Milli Eğitim Bakanlığ̣ Ortaöğretim Genel Müdürlüğü tarafından hazırlanan ve Talim Terbiye Kurulu tarafindan 05.04.2012 tarih ve 20. sayı ile onaylanan "Güzel Sanatlar ve Spor Liseleri Drama Dersi Öğretim Programı”, program geliştirme ilkelerine uygunluk, kuramsal bilgiler, drama dersinin yapılandırılması ve öğretim programı ögeleri kategorileri doğrultusunda, yaratıcı drama alan bilgisi, amaç ve ilkelerine uygunluğu açısından analiz edilmiştir. Ulaşılan bulgular, programdan yapılan doğrudan alıntılarla desteklenmiştir. 


\section{Bulgular ve Yorumlar}

\section{Drama Dersi Öğretim Programının Program Geliştirme İlkelerine Uygunluğuna İlişkin Bulgular}

Program geliştirme, var olan eğitim ve öğretimin kalitesini kontrol etmesi açısından önemli ve dinamik bir süreçtir. Bu nedenle öğretim programlarında deneme sonucunda elde edilen dönütlere göre belirli aralıklarla değerlendirme ve düzeltme yapılması gerekmektedir, çünkü programın bir ögesindeki aksama diğer ögeleri de etkilemektedir. Araştırmada ilk olarak Drama Öğretim Programı hazırlanırken program geliştirme ilkelerine ne ölçüde uygun olarak hazırlandığı tartışılmıştır. Programın bu boyutuna ilişkin değerlendirmeler sonucunda Drama Dersi Öğretim Programı’nın program geliştirme ilkeleri açısından birçok sorun taşıdığı söylenebilir.

Güzel Sanatlar ve Spor Liseleri Drama Dersi Öğretim Programı, başlangıçta 2012 yılında hazırlanmış ve uygulamaya konulmuş gibi anlaşılmaktadır. Ancak yürürlükte olan program, 08.12.2006 tarih ve 392. sayı ile Talim Terbiye Kurulu tarafindan onaylanan ve 6 yıl boyunca uygulanan Anadolu Güzel Sanatlar Lisesi Drama Dersi Öğretim Programı'nın (9.Sınıf) bir tür yenilenmiş ve üzerinde düzenlemeler yapılmış halinden oluşmuştur. Bu açıdan bakıldığında 2012 Drama Dersi Öğretim Programı'nın, drama alanı açısından bir önceki programın eksik ve yanlışlıklarının düzeltilip bir program değerlendirme ve geliştirme çalışması yapılmadan yeniden yayımlanması şeklinde olduğu görülmektedir. 2012 programı kapsamında yapılan değişikliklerin; kuramsal bölümde sadece terimsel değişiklikler ("asıl çalışma" yerine "ana çalışma", "rol oynama” yerine "rol oyunları" sözcükleri kullanılmıştır) şeklinde olduğu, üniteler açısından ise on üniteden altıya indirildiği ve bunların da oyun ve oyun pedagojisi olduğu görülmektedir. Söz gelimi dramanın temeli olan doğaçlamaya sadece iki ünitede yer verilmektedir. Bu yönüyle program geliştirme açısından bakıldığında; programa ilişkin olarak alanda yaşanan sorunların ve gelişmelerin göz ardı edildiği, dersle ilgili paydaşların (öğretmen, öğrenci, veli vb.) ve diğer alan uzmanlarının görüşleri alınmadan programın hazırlandığı söylenebilir. Bu şekli ile yapılan programın program geliştirme ilkelerinden oldukça uzaklaştı̆̆ görülmektedir.

2006 yılında onaylanan programın bir fizik, bir resim öğretmeni ve bir program geliştirme uzmanı tarafindan hazırlandığı, 2012 yılında onaylanan programın ise aynı isimlere ek olarak oyun ve tiyatro pedagogu, müzik öğretmeni, dil, program geliştirme ve ölçme-değerlendirme uzmanları tarafından "yenilendiği”" görülmektedir. Drama Dersi Öğretim Programı’nın hazırlanmasında, üzerinde yer alan isimlerden de anlaşılacağı gibi üniversitelerde doğrudan yaratıcı drama alanında çalışan uzmanlardan ya da amacını yaratıcı drama alanının gelişmesi için belirleyen ve bu konuda çalışmalar yürüten sivil toplum örgütlerinden yararlanılmamış ve onlara görüş sorulmamıştır. Program bu açıdan değerlendirildiğinde, hazırlanma aşamasında özellikle program geliştirme komisyonlarında bulunması zorunlu olan drama alan uzmanlarına ve drama öğretmenlerine (eğitmenlerine) yer verilmediği görülmektedir. Hazırlanan programlarda alan uzmanlarının göz ardı edilmesi, gerek kavramlar gerekse içerik açısından programda birçok bilimsel hatanın programda yer almasına neden olmuştur.

Program geliştirme faaliyetlerinden yaşama dönük olması, aynı zamanda öğrencilerin ihtiyaçlarını karşılaması ve yeteneklerini geliştirmesi beklenmektedir. Ancak söz konusu programda yer alan altı ünitenin büyük bir kısmında, öğrencilerin öğrenmesi gereken doğaçlamaya ve canlandırmaya dayalı etkinliklerin eksik ve yetersiz olduğu görülmektedir. Bu program, güzel sanatlar lisesi öğrencilerinin oyun ve doğaçlamalar aracılığıyla, diğer disiplin ve sanatlarla yeterince bağlantı kurmasını sağlamaması nedeniyle öğrencinin ihtiyaçlarını tam olarak karşılayamamakta ve yaşama dönük görülmemektedir. 


\section{Drama Dersi Öğretim Programında Yer Alan Kuramsal Bilgilere İlişsin Bulgular}

\subsection{Dramanın Tarihsel Gelişim Sürecine İlişkin Bilgiler}

Drama Öğretim Programı’nın “2.1. Eğitimde Dramanın Kısa Tarihçesi” başlıklı alt bölümünde, “...John Dewey, Harriet Finlay-Johnson, Peter Slade, Brian Way Slade, Wihifner Ward, Viola Spolin, Dorothy Heathcote, Hans Wolfgang Nickel, Henry Caldwell Cook, Frank Cisec, Carl Gross, Betty Jone Wagner, Gavin Bolton, McCaslin bu alanın gelişmesine katkıda bulunmuş isimlerdir..." (s.3) tümcesi ile eğitimde yaratıcı drama alanının öncülerinden söz edilmektedir. Bu tümcede önemli eksiklikler ve yanlışlıklar bulunmaktadır. Sözgelimi John Dewey, dünyadaki drama öncüleri arasında belirtilmiştir. Eğitimde yaratıcı drama, eğitim sisteminde yaşantıya dayal1, öğrenenin merkezde olduğu aktif bir öğrenme yöntemidir. John Dewey de çağdaş eğitim anlayışında "eğitimde öğrenenin merkezde olması, eğitimin demokratikleştirilmesi, özgür eğitim ve yaşantıya dayalı öğrenme" gibi yaklaşımların benimsenmesinde önemli adımlar atan dünyadaki önemli eğitimcilerdendir, ancak John Dewey'in drama (yaratıcı drama) alanında bir çalışması bulunmamaktadır. Yaratıcı drama eğitimcileri, alanın kuramsal temellerini açıklarken dönemin eğitim anlayışlarını etkileyen isimlerden de söz etmişler, ancak hiçbir biçimde J. Dewey’i yaratıcı dramanın öncüsü olarak nitelememişlerdir. Bu nedenle J. Dewey’in dramanın öncüleri arasında gösterilmesi yanlış bir bilgidir.

Aynı tümceye göre dünyadaki drama öncülerinden isimleri yanlış veya eksik şekilde belirtilenler şöyle düzeltilmelidir; "Brain Way Slade" yerine "Brain Way" olmal1, 2006 programında Gavin Bolton "Balton" olarak verilmiş ancak 2012 programında bu eksik bilgi düzeltilmiştir. Ayrıca programda Frank Cisec ve Carl Gross yaratıcı drama alanın öncüleri olarak verilmişledir. Oysa bu kişilerden Frank Cisec çocuk psikolojisi alanında Carl Gross da oyunun tanımı ve sınıflandırılması konularında çalışmışlar, oyun ve yaratıcı drama ilişkilerini yer yer kurmalarına karşın bu alanda çalışmaları bulunmamaktadır. Önemli eksiklikleri bulunan bir başka bilgiye göre Betty Jone Wagner programda bir öncü olarak değil, günümüzde eğitimde yaratıcı drama üzerine özellikle Dorothy Heathcote üzerine yapılan çalışmaları yazan kişi olarak yer almalıdır. Ayrıca McCaslin olarak verilen isim Nellie McCaslin olarak yazılmalıdır.

Öğretim Programı’ndaki tarihçe bilgisinde “...Ülkemizde İsmayıl Hakkı Baltacıŏu, Selahattin Çoruh, Emin Özdemir,(...) drama çalışmalarının gelişmesine ve yaygınlaştırılmasında öncülük etmiş isimlerdir...” (s.3) olarak belirtilmiştir. Ancak bu belirlemede önemli eksiklikler bulunmaktadır. Eğitimde yaratıcı drama alanının Türkiye'deki gelişiminde 1980'li yıllara kadar olan çalışmalar, günümüzde yaygın olarak kullanılan dramadan daha çok, ağırlıklı olarak dramatizasyon çalışmalarına yöneliktir. Özellikle İsmail Hakkı Baltacıoğlu, eğitimde yaratıcı drama alanı ya da yönteminin öncüsü olmaktan çok "okul tiyatrosu veya tiyatronun eğitimde kullanılması" gibi düşüncelere sahip olan önemli bir eğitim reformistidir.

Baltacığlu, okullarda tiyatronun yaygınlaştırılmasının öncülüğünü yapmış, bu konuya ilişkin önemli yazılar yayınlamıştır. Ancak sürece dayalı olarak yapılan yaratıcı drama çalışmalarının bugünkü anlam, kapsam ve uygulanma biçiminden uzak "öz tiyatro" anlayışını savunmuştur. Baltacıoğlu'na göre öz tiyatro, batı tiyatrosunun o günkü anlayışının kendi kültürümüze aynen aktarılmasının yanlış anlamalara neden olduğu ve tiyatronun asal ögelerinin sahne, perde, dekor, kostüm, metin, makyaj gibi tiyatroya sonradan katılma ögeler olmadığı anlayışına dayalıdır. Oyuncu, tiyatronun en önemli ögesidir. $\mathrm{O}$, dramatik gerçeği kavramış olarak ve doğaçlama olarak oynamalıdır. Bu nedenle oyuncu, yaratının kaynağıdır. Dramatik gerçeği üretecek olan oyuncudur. Oyuncu bu üretimi, canlandırdığı oyun kişisinin kişiliğine girip canlılığı, devinimi ve dramatik anlamı üreterek yapar. Öz tiyatro, bu anlayıştan yola çıkarak tiyatro sanatının eğitsel gücüne inanmadır. Ona göre tiyatro, doğru bir yaşam örneğidir. Eğer eğitimde gerçekleri yaşatarak öğretmek istiyorsak tiyatro sanatından yararlanabiliriz. Tiyatro yolu ile yaşam bilgisi somut olarak örneklendirilebilir. Bu örnekte rol olan kişi, insan ilişkilerini, toplum yapısını, değer yargılarını tanır. Yalnızca bilgi edinmekle kalmaz, onun nasıl kullanılacağını öğrenir. Tiyatro, özellikle tarih, toplumbilim, felsefe, estetik gibi ders konularının kavranmasına da yardımcı olur (Baltacıoğlu, 1944, 1950; Şener, 1979; Adıgüzel, 2014: 283). 
Baltacıoğlu'nun görüşlerinden de anlaşılacă̆ gibi okul tiyatrosu kavramı tiyatro sanatının okul ortamlarında kullanılmasına yöneliktir. Onun, tiyatronun asal unsurunun oyuncu olduğunu ve metinleri anlayıp daha sonra bunu doğaçlama olarak oynaması gerektiğini savunması, Türkiye'de yaratıcı dramanın başlangıcı gibi yorumlanmasına neden olmuş, pek çok yaratıcı drama yayınında Baltacıoğlu'nun Okul Tiyatrosu anlayışının, yaratıcı drama alanının başlangıcı olduğuna ilişkin görüşler ileri sürülmüştür. Yaratıcı drama alanı, katılımcı odaklı ve doğaçlamaya dayalı çalışmaları içerse de süreç odaklıdır. Bu ders, kendine özgü amaç ve içerikleri ile bağımsız bir sanat alanını kapsar. Bunu yanında aynı zamanda diğer alanların öğretimi için bir yöntem olarak da kullanılabilir. Okul tiyatrosu, doğaçlamadan söz etse dahi yine de seyirci odaklıdır ve çocukların gelişimlerinin tamamlanması, onların seyircilerle kuracağı iletişime bağlanmıştır. Bu durum, benzer özellikler taşımasına rağmen Okul Tiyatrosu'nun yaratıcı drama ile sadece dolaylı bir ilişkisi olduğunu gösterir. Bu nedenle Baltacıŏglu'nun, Türk eğitim sisteminde çok önemli bir öncü olmasına karşın, eğitimde yaratıcı drama alanında da bir öncü olarak değerlendirilmemesi gerekir.

Drama Dersi Öğretim Programı’nın tarihçe bölümünde sadece adları yer alan Selahattin Çoruh ve Emin Özdemir, yazmış oldukları "Okullarda Dramatizasyon" (Çoruh, 1950) ile "Uygulamalı Dramatizasyon" (Özdemir, 1965) kitapları ile yer almalı ve bu kitapların içeriğinde, örnekleri ile verilmeye çalışılan dramatizasyon odaklı çalışmaların olduğu vurgulanmalıdır. Türkiye'de yaratıcı dramanın öncüsü olarak Prof. Dr. İnci San ve Devlet sanatçısı Tamer Levent'ten ve onların başlattığı çalışmalardan daha fazla söz edilmeli, onların yazılı çalışmaları üzerinde durularak Türkiye'de yaratıcı dramanın tarihçesi biçimlendirilmelidir.

“...Alman ekolünün en önemli isimlerinden Prof. Dr. Hans Wolfgang Nickel, 1960’lı yıllarda Almanya’da eğitim fakültelerine 'oyun ve tiyatro' dersi koymuş, rol oyunlarının doğaçlamanın bir alt basamağı olduğunu belirtmiştir. Nickel, ülkemizde Tamer Levent ve İnci San ile çalışarak dramanın bugünkü anlamda uygulamasında ve gelişmesinde büyük rol oynamıştır. Eşi Prof. Dr. Dagmar Dörger ile birlikte 1985 yılından bu yana Çağdaş Drama Derneğinin düzenlediği “Uluslararası Drama Semineri” çalışmalarını yürütmektedir...”(s.3)

Yukarıdaki paragrafta yer alan bilgilendirmelerde, düzeltilmesi gereken yanlışlıklar bulunmaktadır. Almanya'da "eğitimde yaratıcı drama" adıyla doğrudan bir alan bulunmamaktadır, ancak Nickel'in "Okul Oyunu" (Schulspiel) veya "Oyun ve Tiyatro Pedagojisi” (Spiel und Theaterpaedagogik) adıyla öncülüğünü yaptığı çalışmalar, yaratıcı drama alanı ile çok yakından ilişkilidir. Bu nedenle de "Oyun ve Tiyatro Pedagojisi" alanının yaratıcı drama alanı olarak adlandırılması tam olarak doğru değildir. Oyun ve Tiyatro Pedagojisi alanı da oyundan, doğaçlamadan yararlanmasına karşın, daha çok sonuç odaklıdır ve tiyatral bir sunumu önceliğine alır.

Prof. Dr. Hans Wolfgang Nickel, Ankara'da başlayan uluslararası seminerlere katılarak atölye gerçekleştiren ve Türkiye'deki yaratıcı drama çalışmalarına önemli katkılar sağlayan uzmanlardan biridir. Ancak, Drama Dersi Öğretim Programı'nda belirtilen“...Prof. Dr. Hans Wolgang Nickel ve eşi Prof. Dr. Dagmar Dörger ile birlikte 1985 yılından bu yana Çağdaş Drama Derneği tarafindan yürütülmektedir...” tümcesinden, Nickel ve Dörger' in günümüze kadar Uluslararası Eğitimde Yaratıcı Drama Seminerleri'ni başlatan ve hâlâ yürüten isimler olduğu anlaşılmaktadır. Oysa bu seminerlerin başlatıcıları Türkiye'de San ve Levent'dir. Çağdaş Drama Derneği, kurulduğu 1990 y1lından beri bu seminerleri üstlenmiş ve düzenli olarak gerçekleştirmeye de devam etmektedir. Nickel ve Dagmar ise 2012 yılı itibarıyla 21 kez yapılan bu seminerlerin bir kaçına atölye lideri olarak ya da konferans vermek üzere katılmışlardır. Başka bir deyişle, günümüze kadar Uluslararası Eğitimde Yaratıcı Drama Seminerleri'ni devam ettiren kişiler Nicel ya da Dörger değil, bu etkinlikleri düzenli olarak devam ettiren kuruluş olan Çağdaş Drama Derneği'dir.

Drama Dersi Öğretim Programı'nda yer alan dramanın tarihçesinde Çağdaş Drama Derneği'nden (ÇDD) hemen hemen hiç söz edilmemektedir. Oysa Türkiye'de eğitimde yaratıcı drama alanı ve yönteminin gelişmesinde Çağdaş Drama Derneği'nin birinci derecede rolü ve önemi vardır. ÇDD, MEB'deki ilk hizmet içi eğitimlerinde üyeleri ile öğretim elemanı gereksinimi karşılayan, ilköğretimde drama programının hazırlanmasında, eğitim fakültelerinde drama derslerinin yer almasında önemli rol oynamıştır. Ayrıca İlk kez MEB onaylı Yaratıcı 
Drama Eğitmenliği/Liderliği programının oluşturulmasında ve MEB'in pek çok biriminde hizmet içi eğitimlerinin yürütülmesinde çok önemli çalışmaları gerçekleştiren ÇDD gibi bir sivil toplum örgütünün tarihçede yer almaması düşünülemez. Bunların yanında üniversitelerdeki yaratıcı drama eğitimlerine ilişkin lisansüstü programlara, yapılan lisansüstü çalışmalara ve alana yönelik yapılan yayınlara değinilmemesi de tarihçe bilgisi açısından önemli bir eksikliktir.

Programda, biri özel bir işletme diğeri ise bir sivil toplum örgütü olan iki dernekten (Oyun ve Tiyatro Akademisi Derneği) söz edilmektedir. Bu kurumlar, kurucu adları ile birlikte verilmektedir. Ayrıca "Müzik, Oyun ve Tiyatro Pedagogu" olarak komisyonda ismi verilen uzmanın aynı zamanda tarihçede adının verilmesi ve içinde bulunduğu dernek üzerinde durulması, Drama Dersi Öğretim Programı'nın bu kısmının nesnel değil, öznel verilere göre yazılmış olduğunu da göstermektedir. Drama Dersi Öğretim Programının ilk onay tarihi 2006 yılıdır (MEB, 2012). Nitekim 2008 yılında basılan Drama Dersi Öğretim Programı'nın tarihçe kısmında bu bilgiler yer almamaktadır (MEB, 2008: 10). Bu yıllara kadar Oyun ve Tiyatro Akademisi Derneği daha kurulmamıştır. Drama Dersi Öğretim Programı'nın yenilenme çalışması ise 2012 yılında yapılmış ve eklemelerle son halini almıştır. Oyun ve Tiyatro Akademisi Derneği'nin programda belirtildiği gibi 2009 y1lında kurulduğu belirtilmektedir. Yani bir kurum olarak Türkiye'de yaratıcı drama eğitimine katkısı, programın yayın tarihi itibarıyla yalnızca üç yıldır. Üç yıllık bir derneğe hiçbir çalışma ya da alana katkı örneği verilmeden tarihçede diğer kurumlara göre daha fazla yer verilmesi, Drama Öğretim Programı'nın Türkiye'de dramanın tarihçesi bilgisinin verilmesinde önemli eksiklikler ve yanlışlıklar içerdiğini göstermektedir.

\subsection{Dramanın Temel Kavramlarına İlişkin Bilgiler}

Programda; drama, eğitimde drama, eğitsel drama, yaratıcı drama gibi terminolojik karışıklığa neden olacak kavramların bir arada kullanıldığ 1 görülmektedir. Kavramın uluslararası alan yazındaki karşılığı, "eğitimde drama" veya "yaratıcı dramadır". Türkiye'de bu kavramlar "eğitimde yaratıcı drama" olarak kullanılmaktadır. Bu ders "drama" olarak adlandırılabilir ancak dersin bu şekilde adlandırılması, tiyatro ile karıştırılmasına neden olabileceğinden dolayı kavramlar arasındaki benzerlik ve farklılıklara yer verilerek ders, "Drama", "Eğitimde Drama" veya "Yaratıcı Drama" olarak adlandırılabilir.

Drama Dersi Öğretim Programı’nda “2.4. Dramanın Temel Kavramları ve Bileşenleri” alt başlığı ile verilen temel kavramlarda önemli eksiklikler bulunmaktadır. Bu başlık altında "yaratıcılık, iletişim-etkileşim, dramatik oyun, rol oynama, doğaçlama" temel kavramlar olarak verilmiştir. Oysa dramanın temel kavramları arasında "dram, drama, dramatizasyon, dramaturgi, oyun, lider, mekan, konu, atölye, ritüel, çocuk tiyatrosu, çocukların tiyatrosu, eylem, hareket, -mış gibi yapmak, spontanite (kendiliğindenlik), animasyon, psikodrama, sosyadrama, doğaçlama tiyatrosu" gibi kavramlara yer verilmeli ve dramanın bu kavramlarla ilişkisi açıklanmalıdır. Çünkü bu kavramlar aynı zamanda drama alanı ve yöntemini var eden kavramlardır.

Programda "rol oynama" kavramı bir teknik olarak çok açık anlatılmamış, temel özelliği üzerinde hemen hemen hiç durulmamıştır. Ayrıca, drama sürecinin olmazsa olmazı olan doğaçlama ve rol oynama teknikleri yanlış açıklandıkları ve birbirleriyle yanlış ilişkilendirildikleri için bir karışıklık söz konusudur. Programda doğaçlamanın özellikleri şöyle ifade edilmiştir; "Doğaçlamanın iyi ya da kötü olmasının ölçütü de inandırıcılıktır, yani izleyen kişiye inandırıcı gelip gelmemesidir. Doğaçlamada doğru yanlış yoktur. Etkili, ikna edici inandırıcı olan olmayan vardır... oynarken malzeme uygunluğu önemlidir... Doğaçlama yaparken inandırıcı olabileceğimiz rolleri seçmeliyiz..."

"Doğaçlama yaparken inandırıcı olabileceğimiz rolleri seçmeliyiz." tümcesinin aksine bir katılımcı üstlendiği rolü daha inandırıcı olmak/olmamak üzerinden kurmamalı, rolü seçmemeli ve üstlendiği her rolü inandırıcı olarak canlandırmalıdır. Katılımcı çoğunlukla "Ben olsam” diye role girer ve kendine özgü olarak doğaçlamasını yapar. Bu süreçte içten olmak ve tam katılım önemlidir. Ancak doğaçlamalarda ikna edici olma zorunluluğu, yapabileceğimiz rolleri seçme gibi kurallar katılımcıyı tiyatral bir kaygıya götürebilir. Bu durumun doğaçlamanın 
bireylerde yaratacağı özgürleşme, kendini ifade etme ve yaratıcılığı öne çıkarmayı ortadan kaldıracağı kaygısına neden olabilir. Bu nedenle Drama Dersi Öğretim Programı'nda mutlaka doğaçlamanın temel ilkelerine ve kurallarına yer verilmelidir.

Drama Dersi Öğretim Programı’nda yer alan “doğaçlama” için yapılan tanım, doğaçlamanın birçok özelliğini yansıtmamaktadır. Örneğin spontanite (kendiliğindenlik), dramatik an, bir metnin zorunlu olmayışı, bireysel olabileceği gibi ikili, üçlü veya küçük / büyük grup ile birlikte yapılan doğaçlamalar gibi özelliklere yer verilmelidir.

Doğaçlama ve rol oynama, tüm tekniklerin çıkış noktası olsa da bu iki kavram teknikler başlığı altında ele alınmalı ve dramanın diğer tekniklerine de örneklerle yer verilmelidir. Programda doğaçlama iki temel teknik olarak verilmiş, bu teknikler de "Sınırlandırılmış Doğaçlama Tekniği, Özgür Doğaçlama Tekniği” olarak adlandırılmıştır. Doğaçlama başı başına bir tekniktir. Yapılan adlandırmaların doğaçlamanın uygulanmasına ilişkin önerilebilecek biçimler olarak değerlendirilmesi oluşan kavram kargaşasını önleyebilir.

Programda “2.4.2. Temel Bileşenler” başlığı alt başlığında, dramanın temel bileşenleri olarak verilen başlıklar, çeviri dipnotu (Çevik, 2006) ile şu şekilde gösterilmiştir:

- Bedene Dayalı Oyunlar ve Alıştırmaları

- Materyal Oyunları ve Alıştırmaları

- İletişim ve Etkileşim Oyunları ve Alıştırmaları

- Sözel Oyunlar ve Alıştırmaları

- Grup Dinamiği Oyunları ve Alıştırmaları

- Rol Oyunları ve Alıştırmaları

- Doğaçlama

- B. Brecht Öğrenme ve Öğretme Oyunları

- Tiyatro

Çeviri metnin özgün adından anlaşılacağı gibi dramanın temel bileşenleri olarak verilen kavramlar Oyun ve Oyun Pedagojisinin (metnin sonunda da belirtildiği gibi tiyatronun) temel formlarıdır. Metnin özgün halinde bileşenler olarak verilen öğeler dramanın değil “oyunun farklı alanları-biçimleri” olarak verilmiştir. Bu başlıkların Almanca karş1lıkları 1. Körperübungen-Körperspiele, 2.Materialspiele und Übungen, 3.Interaktionübungen und Spiele, 4.Rhetorische Übungen und Spiele, 5.Gruppendynamische Übungen und Spiele, 6.Rollenübungen und Rollenspiele, 7.Lernstück-Lehrstück, 8.Professionelles Theater, 9.Schulteater/Amateurtheater, 10.Fest-Schulfest-Stadtteilarbeit-Animation olarak verilmiştir. Almanca özgün metinde verilen oyun formları maddelerinden de anlaşılacağı gibi 7.maddeye B.Brecht eklenmiş ki kendisi Öğretici Oyunlar kavramının öncüsüdür. 8, 9 ve 10. maddelerde belirtilen Profesyonel Tiyatro, Okul Tiyatrosu/Amatör Tiyatro ve Festival-Okul Festivali-Bölge(Semt) Festivalleri-Animasyon maddeleri Drama Dersi Öğretim Programı'nda 9. maddede tiyatro olarak verilmiş, özgün metinde yer almayan doğaçlamaya ise 7. madde olarak yer verilmiştir.

Temel bileşenler, dramanın tüm ögelerini kapsamalıdır. Bu ögeler ise konu-düşünce, grup, yaşantı, oyun/ oyunsu süreç, teknikler, lider ve mekândır. Drama Dersi Öğretim Programı'nda dramanın bileşenleri olarak verilen kavramlar, drama sürecinde karşılaşılan ve drama ile ilgili kavramlar olmakla birlikte tam olarak dramanın bileşenleri değil, oyunun ve oyun pedagojisinin temel bileşenleridir. Bu bilgilendirme, Hans Wolfgang Nickel ve Dagmar Dörger tarafından "Amatörler İçin Tiyatro Çalışması" (Theaterarbeit für Amateure) olarak yazılmış bir ders dokümanına dayanmaktadır. Metnin özgün başlığı "Spielpaedagogische Grundformen" dur. Metin, Nickel tarafindan "Spiel-Theater-, Interaktionspaedagogik, Hilfen für den Spielleiter, Heft 16 (Oyun, Tiyatro ve Etkileşim Pedagojisi, Grup Yöneticisine Yardım İçin Kitapçık), olarak 1976 yılında yayınlanmıştır. Başlığın 
çevirisi de "Pedagojik Olarak Oyunun Temel Formları/Biçimleri”'dir. Bu metin yine Çevik tarafından Türkçe’ye çevrilmiştir. Buna karşın metnin özgün halinde oyun alanının değişik formları olduğu halde bu maddeleri dramanın temel bileşenleri olarak adlandırmak önemli bir yanlışlığa neden olmaktadır. Sözgelimi drama, oyunun tüm özelliklerinden sürecin her aşamasında yararlanır ancak temel bileşen olarak sadece "dramatik oyun" ele alınmıştır. Tiyatro, başlı başına bir sanat türüdür ve dramayı besleyen iki alandan biridir. Özgün metinde verilen üç tiyatro yaklaşımı, Drama Dersi Öğretim Programında "Tiyatro" olarak verilmiştir ki bu yanlış bir yönlendirmedir. Tüm alan yazın göstermektedir ki drama günümüzde tiyatrodan farklı, ancak onunla ilişkili bir kavramdır. Ancak tiyatro, bu metinde verildiği gibi, hiçbir biçimde dramanın temel bileşeni değildir. Ayrıca B. Brecht'in “Öğrenme ve Öğretme Oyunları" (s.9) olarak verilen "Öğretici Oyunları" (Lehrstück) da yine epik tiyatroda Brecht'in toplum eğitimine yönelik savunduğu ve uyguladığ temel bileşeni olarak adlandırılamaz. Öğretici Oyunlar, ancak içerik ve yapısı gereği drama ile ilişkili kavramlar arasında yer alabilir ve bu metinlerden drama liderleri değişik amaçlar için yararlanabilir.

Almanca metnin sonunda, tiyatro ve bu oyunların ilişkisi kurulurken hemen tüm oyun türlerinin seyirci ile ilişkisi üzerinde durulmakta ve tüm oyunların seyirci için yapıldığına yönelik bilgilendirmeler verilmektedir. Sadece bu bilgi bile bu kavramların dramanın temel bileşenleri olarak adlandırılamayacağını gösterir. Zira drama süreç odaklıdır ve çalışmalarda iç izleyici söz konusudur, tiyatro ise sonuç odaklıdır ve seyirci için yapılır. Nickel ve Dörger'in metnindeki tiyatro maddesine ilişkin açıklamalarında yer alan "tiyatro için bütün oyun formlarında seyirci ön plandadır" sözü bu görüşü doğrulamaktadır.

“4. Drama Dersi Öğretim Programı’nın Temel Yaklaşımı” alt başlı̆̆ı altında geçen “... konular, öğrencilerde drama bilinci oluşturacak nitelikte ele alınmış..."(s.11) tümcesinde yer alan "drama bilinci” kavramından ne kast edildiği tam olarak anlaşılmamaktadır. Programda verilen konu ya da etkinlik örneklerine bakıldığında ve oyun ağırlıklı çalışmaların oransal olarak fazlalığı düşünüldüğünde, tam tersine drama bilinci yerine konu ve etkinliklerin oyun bilinci oluşturmaya yönelik olduğu görülmektedir. Ayrıca yine bu başlık altında verilen “... Dramanın diğer tekniklere oranla üstünlüğü...” (s.11). gibi vurgulamalarda dramanın bir teknik olarak ele alındığı görülmektedir. Oysa yaratıcı drama, kendi teknikleri olan bir yöntemdir ve hiçbir biçimde bir teknik olarak adlandırılamaz Yine bu başlık altında verilen “...Drama Dersi Öğretim Programı’nda kazanımlar, birçok zihinsel beceriyi vurgulamakta, öğrenme süreçlerinde ise aktif öğrenme yöntemlerinin ve öğretimsel işlerin kullanımını gerektirmektedir. Programda bu yöntemlerin kullanıldı̆̆ı etkinlik örneklerine yer verilmiştir..." (s12) tümcesinde verilen bu yöntemlerin kullanıldığı sözünden bir şey anlaşılmamakta ve programda kast edilen yöntemlerin kullanımına ilişkin örnekler yer almamaktadır. Drama Dersi Öğretim Programı, dramanın yöntem boyutundan daha çok, başlı başına bir ders olan drama ve tekniklerini üzerine oluşturulmalıdır. Oysa programda belirtildiği gibi farklı "yöntemlere" yer verilmediği görülmektedir. Bir eğitim programında, kazanımların/amaçların işe nasıl dönüşeceği, öğrencinin nasıl etkinliğe katılacağının göstergelerini, kullanılan strateji, yöntem ve teknikler belirler. Drama Dersi Öğretim Programı’nda “nasıl?” sorusuna ilişkin yeterli yanıt bulunmamakta, kullanılacak strateji, yöntem ve teknikler üzerinde de fazla durulmamaktadır.

\section{Drama Dersi Öğretim Programında Drama Sürecinin Yapılandırılmasına İlişkin Bulgular}

Drama Dersi Öğretim Programında ‘2.3. Drama Süreci’ alt başlığı ile yer alan bilgilendirmeler arasında “... drama sürecinin oluşabilmesi için öncelikle drama lideri, drama grubu, materyaller ve uygun ortamın olması gerekir. Bunlar dramanın unsurları olarak tanımlanabilir..." (s.5) denilerek dramanın unsurları verilmiştir. Oysa bir eğitim programı, programın ögeleri $(5 \mathrm{~N} 1 \mathrm{~K})$ en ince ayrıntısına kadar düşünülerek hazırlanmalıdır. Drama lideri tarafından drama süreci de tüm bu açılardan ayrıntılı bir şekilde düşünülüp planlanmalıdır. Hatta olası aksaklıklara karşı alınacak önlemler düşünülmeli veya aynı amaçlara yönelik birden fazla plan oluşturulmalıdır. Ancak lider, bazen tasarlanan plana rağmen drama sürecinin grup üyelerinin yaşantıları ve ortaya çıkan oluşumlarla yönlenebilen, spontane (kendiliğinden) gelişmelere açık olduğunu unutmamalıdır. Programda bunlara ek olarak drama sürecinin oluşması için olmazsa olmaz olan konu-tema, doğaçlama-rol oynama gibi bileşenlere de yer 
verilmemiştir. Ancak, eğer bir drama çalışmasında canlandırmaya dayalı etkinlikler yoksa ve bu canlandırmaların çoğunluğu da doğaçlamaya dayalı değilse o drama çalışması çok eksiktir ve tam olarak bir drama sürecini oluşturmaz.

Drama öğretim programında yer alan "Program daha çok çerçeve plan niteliğindedir. Asıl program, çalışma sırasında grup ile şekillenir" (s.6) ifadesiyle ortaya çıkan anlam, uygulanacak planın ana hatlarıyla belirlenip çalışmaya başladıktan sonra ayrıntıların ortaya çıkacağı yönündedir ki bu durum drama lideri ya da öğretmenini "rastgele" bir anlayışa yöneltmektedir. Bu da özellikle yeterli drama eğitimi almayan öğretmenlerin çerçeve programı biçimlendirme ve sürecini tamamlamada önemli sorunlar yaşamalarına ve beklenen kazanımlara ulaşılmamasına neden olabilir.

Drama Öğretim Programı'nın aynı alt başlığı altında drama dersinin yapılandırılmasına yönelik olarak dramanın aşamaları "Isınma, Ana Çalışma (oyun/doğaçlama, rol oyunları), Değerlendirme" başlıkları altında verilmektedir (s.6). 2006 programında da ikinci aşama Asıl Çalışma olarak yer almaktadır. Bu aşamada “...rol oyunları ile doğaçlamaya geçiş yapılır. Rol oyunları, doğaçlamanın temelidir...” belirlemesinin hiçbir bilimsel dayanağı bulunmaktadır. "Rol Oyunları" olarak adlandırılan kavram, daha çok rol oynama olarak adlandırılır ki her iki teknik eş zamanlı olarak işe koşulur yani rol oynarken doğaçlama yapılabilir, doğaçlama yapılırken de rol oynanabilir. Bu nedenle "rol oyunları, doğaçlamanın temelidir" belirlemesi tam olarak doğru kabul edilemez.

Herhangi bir drama aşamasının "asıl” veya "ana” çalışma olarak nitelendirilmesi, eğitim programının bütünlüğü açısından düşünüldüğünde yanlış bir adlandırmadır. Bir programın oluşturulması ve uygulanmasında giriş niteliği taşıyan ısınma çalışmaları veya değerlendirme aşamaları, doğaçlama ve rol oynama etkinliklerinin çoğunlukla yapıldığı aşamadan daha az değerli değildir. Bu nedenle drama çalışmalarının belirli bölümünü “asıl ya da ana" çalışma olarak belirlemek, diğer aşamaların daha az önemli olduğu tartışmalarına meydan vermektedir. Hâlbuki drama ders planlarında her aşama aynı amaca hizmet etmeli, birbirini desteklemeli ve aşamalar arasında sağlam bağlantılar kurulmalıdır. Dolayısıyla her aşamanın süreçte bir işlevi ve önemi vardır. Bu nedenle herhangi bir aşamanın "asıl ya da ana çalışma" olarak adlandırılması uygun değildir. Ayrıca dramanın olmazsa olmazlarından olan "canlandırma" kavramı, alanın kendine özgü kavramıdır. Yaratıcılık da dramanın en üst düzeyde ana amaçlarından biridir. Bu nedenle yaratıcı dramanın yapılandırılmasında aşamaların, "Isınma/Hazırlık, Canlandırma ve Değerlendirme" gibi ana başlıklar altında ele alınması daha uygun olmaktadır (Adıgüzel, 2006: 2014).

Programın ısınma aşamasının özellikleri anlatılırken nelerin ısınma etkinlikleri olabileceğine ilişkin verilen örneklerin içinde uyum ve güven çalışmalarına yönelik hiçbir atıfta bulunulmaması, ısınma çalışmalarının sadece fiziksel etkinlikler gibi algılanmasına neden olmaktadır. Isınma aşamasında yapılan çalışmalara çocuk oyunlarının yanı sıra "bedene dayalı oyunlar, ritm ve müzik eşliğinde 1sınma, fiziksel ısınma hareketleri” örnek olarak verilmiştir. Bu bilgilerden hareketle, ısınmanın sadece oyunlarla gerçekleşeceği algısı oluşmaktadır, oysa oyunlar öğrencinin bedensel ve psikolojik olarak bir sonraki aşamaya hazırlanmasında yararlanılabilecek araçlardan sadece bir tanesini oluşturur.

Oyunun tüm özellikleri dramanın her basamağında yer alabilir. Ancak "bedene dayalı oyun" olarak isimlendirilmiş bir oyun türü gibi adlandırmalar oyunun daha dar anlamlandırılmasına neden olabilir. Ayrıca bu aşamadaki etkinlikler için verilen örnekler,“ fiziksel ısınma hareketleri” gibi tamamen fiziksel 1sınmaya dayalı örneklerdir. Dramada önemli olan zihinsel ve duygusal ssınma ile hazırlıktır ki bu durum programda göz ardı edilmektedir.

Türkiye'de yaratıcı drama uygulamalarında "rol oyunları" adlı bir kavram yaygın olarak kullanılmamaktadır. Kavram Almanca'daki "Rollenspielen” kavramının karşılı̆ğ olarak kullanılmaktadır. Bu nedenle Türkçeye "rol oynama" olarak çevrilmesi daha uygudur. Programda 1sınma aşamasından sonraki aşama "rol oynama çalışmaları / rol oyunları" olarak yer almaktadır. Rol oynama, dramanın tıpkı doğaçlama gibi olmazsa olmaz teknik- 
lerinden biridir. Rol oynama, herhangi bir drama sürecinde başkasına ait bir görevi kurgusal olarak üstlenmek ve onunmuş gibi yaparak canlandırmaktır. Bu nedenle rol oynama hiçbir biçimde yaratıcı dramada bir aşama olarak adlandırılamaz. Programda "rol oynama çalışmalarında birey bedenini sesini kısaca kendini keşfeder, doğaçlamalara hazırlanır" ifadesinden çıkan anlam ise rol oynamanın doğaçlama öncesinde var olan bir hazırlık aşaması gibi olduğudur. Oysa drama sürecinde birey rol oynamaya başladığı an zaten doğal bir doğaçlama sürecine girmiş olur. Dramanın bu iki asal tekniği süreçte birbirlerine eş zamanlı olarak yer alır.

Programda değerlendirme aşamasına ilişkin olarak belirtilen noktalardan bazıları şu şekildedir: “...Değerlendirme belirli bir aşamadan sonra yapılabilir. Her çalışma sonunda değerlendirme yapılması uygun değildir. Çalışmayı yöneten kişi, değerlendirmeyi gözlemleriyle yapabilir..." (s.7). "Drama süreci doğaçlamanın ardından rahatlama (soğuma) ile son bulur. Rahatlama bir anlamda oyunun büyüsünden kurtulup gerçek hayata dönmektir. Oyuna dışardan bakarak yaşananlar sorgulanır, eleştirilir. Bu aynı zamanda oyundaki çatışmanın geriliminden bedensel ve psikolojik olarak kurtulmaktır..." Bu gibi tümceler eğitim programının ögeleri açısından yanlış anlamalara açıktır. Program ögeleri açısından değerlendirme, genel olarak kazanımların ölçüldüğü aşama olarak ele alınır. Her aşamadan sonra gerekli durumlarda da değerlendirme yapılabilir. Bu şekilde gerçekleşen değerlendirme etkinlikleri, sadece o etkinliğe ilişkin görüş, düşünce ve duyguların paylaşıldığı "ara değerlendirmeler" olarak adlandırılır. Bu nedenle "...Çalışmayı yöneten kişi, değerlendirmeyi gözlemleriyle yapabilir..." gibi bir tümce değerlendirme etkinlikleri açısından son derece eksiktir.

Drama süreci, canlandırmanın ardından her zaman soğuma olarak adlandırılan etkinlik ile son bulmaz. Hiçbir katılımcı, sporcu veya işleyen bir makine değildir. Bu aşamanın da adı bu nedenle hiçbir biçimde "soğuma" olarak adlandırılamaz. Ayrıca aşamanın adı "rahatlama" olarak da adlandırılamaz. Çünkü bu şekilde gerçekleşen bir adlandırma ile öğretmen her çalışmanın sonunda mutlaka bir rahatlama çalışması yapmayı zorunlu olarak görebilir. Oysa rahatlama da drama süreci içeresindeki etkinliklerden biridir ve özellikle harekete dayalı 1sınma ya da canlandırma etkinliklerinden sonra, gereksinim duyulduğunda yapılabilecek bir çalışmadır. Öğretmen/ lider grubun yapısı ve yapılan çalışmanın özelliğine göre değerlendirme aşamasını farklı biçimlerde ve etkinlerle uygulayabilir.

Programda ana unsur olarak "materyaller" de ele alınmıştır. Elbette materyaller drama sürecinde önemli ögelerden biridir ve kullanılacak olan materyaller lider tarafından önceden eksiksiz sağlanmış olmalıdır. Ancak kostümler, cd çalar vb. zaten dramanın gerçekleştirildiği ortama aittir. Materyaller, "ortam” başlığı altında değerlendirilebilir. Ayrıca uygun ortam başlığı açıklanırken drama çalışmaları için dış dünyanın gürültüsünden yalıtılmış, kapalı ortamların daha uygun olduğu vurgulanmıştır. Oysa drama çalışması, içeriğine ve amaçlarına göre uygun olan drama sınıfi, alış veriş merkezleri, sokak, müzeler, ören yerleri, tarihi yerler gibi her ortamda gerçekleştirilir. Drama süreci başlığı altında belirtilen "uygun ortam" alt başlığında "drama amaca uygun her yerde yapılabilir" eklemesi yapılmalıdır. Programın amacına göre hazırlanmış hemen her ortamda drama dersi ya da etkinlikleri yapılabilir. Bunların yanı sıra drama sürecindeki unsurlardan önemli biri olan "çalışmanın kendisi”nin, unsurların arasında ele alınmamış olması önemli bir eksikliktir.

\section{Drama Dersi Öğretim Programı’nın Yapısına İlişkin Bulgular}

Bu başlık altında Drama Dersi Öğretim Programı; amaç, beceriler, değerler, üniteler, kazanımlar, etkinlikler ve ölçme değerlendirme ögeleri açısından ayrı başlıklar altında değerlendirilmiştir.

\subsection{Amaç}

Programda, Drama Dersi Öğretim Programı'nın Yapısı (s.12) alt başlığı ile verilen bölümde, programın genel amaçları öğrencilerin; öz bilinç ve öz yönetimini geliştirmelerini, öz güven kazanarak kendilerini doğru ifade etmelerini, drama yoluyla yaratıcılıklarını ve estetik duygularını geliştirmelerini, algı alanını genişletip, ilgi ve yeteneklerini geliştirmelerini, kendileri ve çevreleri ile iletişim ve etkileşim kurmalarını, drama yoluyla anlama, anlatma, dinleme ve imgelem gücünü geliştirmelerini, gözlemlerini, izlenimlerini, duygularını ve imgelemle- 
rini drama tekniklerini kullanarak ifade etmelerini, kendi bedenine, duygularına, düşüncelerine ve çevresinde olup bitenlere karşı duyarlı ve bilinçli olmalarını, drama yaşantısının somut olarak duyumsanmasıyla evrensel, toplumsal, moral, soyut ve etik kavramları anlamlandırmalarını, drama etkinliği ile grup heyecanı, işbirliği ve grup dinamizmi kazanmalarını, empati kurma, doğaçlama ve rol oynama becerilerini geliştirmelerini, araştırma istek ve duygusunu geliştirmelerini, oyun oynayarak ruhsal ve bedensel açıdan rahatlamalarını amaçlamaktadır (s.12). Amaçlar, bir programın yönünü ve içeriğini gösteren en temel ögelerden biridir. Bir dersin ünitelerinin ve kazanımlarının, programda belirtilen amaçlara uygun olarak hazırlanması ve programın uygulamasının ardından öğrencinin öngörülen amaçlara ulaşması beklenir. Ancak ünitelerin konu başlıkları ve 36 kazanımı arasında programın genel amaçlarını gerçekleştirecek kazanımların çok azını karşılayabildiği görülmektedir.

\subsection{Kazanımlar}

Birinci ünite olan “İlk karşılaşma ve Grup Dinamiği Oluşturma” başlığında 7 kazanım bulunmaktadır. Bu kazanımların hiçbirinde herhangi bir canlandırma etkinliği bulunmamaktadır. "Etkinlik Örnekleri” olarak verilen kısımlarda diyaloglar ve farklı formlarda yürüyüşlerin dolaylı olarak drama teknikleri kapsamında işleneceği belirtilmektedir. Ancak ne kazanım ne de etkinlik örneği, dramanın bu özelliğine hizmet etmektedir. Ayrıca “Açıklamalar” kısmında belirtilen üç uyarı (!) tümcesinde gerçekleştirildiği iddia edilen kazanımların gerçekleşmesine yönelik etkinlik içermediği görülür. "Bu ünite ile öğrencilerin sevgi, saygı, paylaşımcılık, öz bilinç, öz güven değerlerine ulaşması beklenir, Bu ünitenin sonunda öğrencilerin bedenini kullanabilme, bağımsız düşünebilme, drama tekniklerini kullanabilme (...) becerilerini kazanması beklenir" tümcelerinin karşılığı olacak bir kazanım ve etkinlik bulunmamaktadır. Yedinci kazanım olan "Grupla öykü oluşturur” kazanımında, bir öykünün grupla birlikte oluşturulacağı bilgisi vardır, ancak öykünün canlandırılmasına ilişkin bir uyarı ya da yönerge bulunmamaktadır. Bu ünitedeki kazanımların büyük bir kısmı, belirtilen genel amaçlara ulaşmada yetersizdir.

Ünite 1'de "Eş zamanı duygu, form ve diyalog alıştırmaları" başlığında verilen "Sevinçli bir yaşlı ile s1kılgan bir çocuk karşılaşırlar ve diyalog kurarlar." (s.21) etkinlik örneği, "grup içinde kendini ifade eder" kazanımını gerçekleştirmek üzere oluşturulan bir etkinliktir. Bu etkinlikte geçen "diyalog kurma" ifadesinden, öğrencilerin doğaçlama, rol oynama ve canlandırma etkinliği yapacağı tam olarak anlaşılmamaktadır. Ayrıca öğrencilerin sevinçli bir yaşlı veya sıkılgan bir çocuk rolünde olması durumu, "grup içinde kendini ifade eder" kazanımına hizmet etmemektedir. Çünkü öğrenci burada doğrudan kendini ifade edememekte ve üstlendiği rol çerçevesinde diyalog kurmaktadır. Ayrıca doğaçlamanın olmadığı bir drama dersi olamayacağına göre söz konusu doğaçlamanın diyalog kurularak verilebileceği düşüncesi yanlıştır. Diyalog her biçimde kurulabilir. Bunun için bir doğaçlama süreci ve dramatik bir durum gereklidir. Ayrıca birinci ünite kapsamında ele alınan içerikte iletişim etkileşim, grup dinamiği konuları olmasına karşın belirtilen etkinliklerin güven, uyum, gözlem, denge gibi etkinliklerden uzak olduğu görülür.

İkinci ünite olan “İletişim Oyun ve Alıştırmaları” başlığında 5 kazanım bulunmaktadır. Bu ünitede yer yer diyaloglara dayalı örnekler yer almasına karşın bu diyalogların hangi teknikle yapılacağı bilgisi bulunmamaktadır. Buna karşın "Açıklamalar” bölümünde uyarı tümceleri olarak "Bu ünite ile öğrencilerin hoşgörü, saygı, dayanışma, öz güven ve estetik değerlere ulaşması, bağımsız düşünebilme, drama tekniklerini kullanabilme, imgelem geliştirmeleri (...) becerilerini kazanması beklenir” tümcelerinin karşıllğı olarak belirtilen kazanım ve etkinliklere rastlanmamaktadır. Sözgelimi hangi kazanım ve etkinlik örneği ile estetik değerlere ulaşılacağı, hangi drama tekniklerinin kullanılacağı gibi amaçlar belirsizliğini korumaktadır. "İletişim Oyun ve Alıştırmaları" ünitesinin içeriğinde "diyalog çalışmaları ile role hazırlanmak" olarak nitelendirilen çalışmalar eksik ve yanlış ifade edilmiştir. Drama dersinde bireyler rol oynama ve doğaçlamalarla canlandırmalar kurgular, diyaloglar da zaten rol içindeyken oluşur. Kazanımlar, ünite konu başlığına tam olarak uymamaktadır. Etkinliklerin de konu başlığına daha uygun biçimde yeniden yapılandırılması gerekir. 
Üçüncü ünite olan "Rol Oyunları" başlığında 4 kazanım bulunmaktadır. Doğaçlama ve rol oynama tekniklerinin, kazanım ve etkinlik örneği olarak verildiği ünitede başka tekniğe yer verilmemektedir. Ayrıca bu başlık altında yer alan tekniklerin tüm ünitelerde olması gerekir. Ünite başlığının doğaçlama ve rol oynamaya giriş olarak değiştirilmesi gerekir. Rol, toplumsal roller, mış gibi yapmak, kendiliğindenlik gibi kavramlar bu ve diğer ünitelerde hem kavramsal hem de uygulamalı olarak verilmelidir. Yine ünitede verilen “Açılamalar” bölümünde verilen tümceler diğerleri ile benzerlikler göstermesine karşın yine genel amaçlara ulaştırmaktan uzak olduğu görülmektedir.

Dördüncü ünite olan “Bedene Dayalı Oyun ve Alıştırmaları” başlığında 5 kazanım bulunmaktadır. Bu ünitede adından da anlaşılacağı gibi bedensel oyunlara ve beden aracılığı ile bedensel ifade araçlarına ilişkin örneklemelere odaklanılmaktadır. Ancak bu ünitede de donuk imge dışında başka bir drama tekniğine yer vermemektedir. Bedenin bir ifade aracı olduğu kazanımlarda vurgulandığ 1 halde ünite başlığının "Bedene Dayalı Oyunlar" olarak verilmesi program açısından bir tutarsızlık oluşturmaktadır. Doğaçlama ve rol oynamanın beklendiği ve isim olarak hiç adlandırılmayan canlandırma aşaması çok zayıftır. Bu ünitede farklı tekniklere de yer verilmelidir. Kazanımlar ve etkinlikler incelendiğinde bu ünite için ayrılan 5 ders saatinin uzun olduğu da söylenebilir.

Beşinci ünite olan "Ritim-Ses ve Devinim” başlığında 7 kazanım bulunmaktadır. Ritim, ses ve devinime odaklanan bu ünitede, dramanın bir aracı sayılabilecek müzik ve ögelerinden yeterince yararlanılmadığı görülmektedir. Doğaçlama olarak verilen kazanımda tam bir doğaçlama etkinliği görülememektedir. Açılamalar kısmında drama tekniklerini kullanabilme becerisinin geliştirilmesi beklenir tümcesine rağmen bu amaçların kazanım ve örnek etkinliklerde karşılığının olmadığı anlaşılır.

Altıncı ünite olan "Materyal Oyun ve Alıştırmaları" başlığında 7 kazanım bulunmaktadır. Bu kazanımlar arasında materyaller aracılığı ile öykü kurgulama, resim yapma, görsel eserleri yorumlama ve oynama gibi tümceler yer almasına karşın doğaçlama ve diğer teknikler üzerinde yeterince durulmadığı görülür. Etkinlik örneklerinde verilen “...öykü kurgulanır ve oynanır” tümcesinde yer alan "oynamak” eyleminin tam olarak doğaçlama, rol oynama ve canlandırmayı kapsadığı anlaşılmamaktadır. Bu ünitede belirtilen kazanım ve etkinliklerin “Açıklamalar” kısmında belirtilen genel amaçlara ulaştırması kolay görünmemektedir. Diğer sanat alanlarında dramanın kullanımı; sadece bu ünitede verilmiştir. Oysa dramanın tüm sanat dallarıyla ilişkisi vardır ve tüm ünitelerde bu sanat türleri birer araç olarak yer alabilir ve böylece sanatlar ile drama ilişkisi daha rahat kullanılabilir. $\mathrm{Bu}$ açıdan kazanımlar ve etkinlikler çok eksiktir.

Kazanımlar, genel amaca ulaşma açısından değerlendirildiğinde, “özbilinç ve özyönetim geliştirme, özgüven kazanarak kendini doğru ifade etme, algı alanını genişletip ilgi ve yetenek geliştirme, gözlem, izlenim, duygu ve imgelemlerini drama tekniklerini kullanarak ifade etme, drama yaşantısının somut olarak duyumsanmasıyla evrensel, toplumsal, moral, soyut ve etik kavramları anlamlandırma, empati kurma, doğaçlama ve rol oynama becerilerini geliştirme, araştırma istek ve duygusunu geliştirme gibi amaçların hazırlanan kazanımlarla karşılanamayacağ1 ve programda bu amaçlara dönük kazanımlara yer verilmediği görülmektedir.

\section{3. İçerik (Ünite/Konu)}

Programa göre, Drama dersi 2006 programına göre dört eksik ünite ile toplam 6 ünite olarak oluşturulmuştur. "Dramanın Bileşenleri” başlığı altında verilen 9 maddenin kısaltılarak biraz da farklı adlandırmalar eklenmesiyle ünite başlıklarını oluşturduğu görülmektedir (s.16). 2006 programında 10 olan ünite sayısı 2012 programında 6'ya düşürülmüş, kazanım sayısı da 2006 programında 44 iken 2012 programında 36'ya indirilmiştir. Ders saatleri ise her iki program süresince 36 ders saati olarak bir değişikliğe uğramamıştır. Drama Dersi Öğretim Programı'na göre ünite başlıkları ve açılımları şöyledir:

Ünite 1: İlk Karşılaşma ve Grup Dinamiği Oluşturma

(Isınma Oyun ve Alıştırmaları / Grup Dinamiği Oluşturma) 
Ünite 2: İletişim Oyun ve Alıştırmaları

(Diyalog Oyun ve Alıştırmaları / Statü Alıştırmaları)

Ünite 3: Rol Oyunlar1

(Rol Oyunlarına Giriş / Doğaçlama)

Ünite 4: Bedene Dayalı Oyunlar ve Alıştırmaları

(Bedene Dayalı Oyunlar ve Çocuk Oyunları / Bedene Dayalı Alıştırmalar)

Ünite 5: Ritim, Ses ve Devinim

(Duyu Alıştırmaları / Ritim, Ses ve Devinim Alıştırmaları)

Ünite 6: Materyal Oyun ve Alıştırmaları

(Materyal Oyunlarıyla Sınırlandırılmış Doğaçlama / Sanat Eserlerine Dayalı Sınırlandırılmış Doğaçlama)

Drama Dersi Öğretim Programı'nın ünite başlıklarına bakıldığında, içeriğin drama alanın amaç boyutundan çok araç boyutuna uygun konu ve etkinliklerden oluşturulduğu görülür. Programın ağırlıklı alanları, grup dinamiği, ritim, ses, devinim, oyun, ısınma oyunları, bedene dayalı oyunlar, materyal oyunları gibi çoğunlukla oyun türlerine dönük olarak yer aldığı görülür. Dramanın olmazsa olmazı olan doğaçlama ve rol oynama tekniklerinin sadece bir ünitede "rol oyunları" başlığı altında verilmesi bir drama öğretim programı açısından düşünülemez.

Doğaçlama, Drama Dersi Öğretim Programı'nın tüm saatlerinde mutlaka olması gereken bir tekniktir. Genel amaçlar arasında yer almasına karşın drama tekniklerine yönelik etkinliklerin bir iki örnek dışında hiç olmadığ1 da görülmektedir. Aynı biçimde canlandırma etkinliklerinin de programda ağırlıklı olarak bulunması gerekirken bunun yerine çoğunlukla oyun oynama etkinliklerinin yer aldığı görülmektedir. Bu durumun drama alanının oyun etkinliğinden başka bir şey olmadığ 1 yanlış algısına neden olmaktan başka bir katkısı olamaz.

İçerik, bir öğretim programında, öğrencinin hazır bulunurluk düzeyi, gelişim düzeyi, çevresel koşullar dikkate alınarak öğrencilerin "neleri” öğreneceklerinin belirlenmesidir. Ünitelerin yapılandırılmasında dramanın kuramsal yanına hiç değinilmediği görülmektedir. Oysa temel kavramlar, tarihçe, teknikler ve örnek uygulamalara yer verilmelidir. Uygulamanın ağırlıkta olduğu görünümü veren program, daha çok oyun etkinlikleri ile doldurulmuş, dramatik kurguya hemen hemen hiç yer verilmediği görülmüştür.

Drama gibi yaşantıya dayalı bir alan için önce kişiler arası iletişim ve etkileşimin sağlanarak oluşturulan grup dinamizminin ardından temel oyun etkinlikleri, doğaçlama ve rol oynamaya giriş, doğaçlamadaki kurallar, öğretmenin role girmesi, rol içinde yazma, toplantı gibi tekniklere yer verilmeli, dramatik kurgunun bileşenleri ünitelere dağıtılmalıdır. Özetle, bağımsız bir ders olarak önerilen programda, kuramsal bilgiler ile uygulama çalışmaları bir bütünlük ve denge içerisinde hazırlanmalı ve uygulanmalıdır. Dramanın açık bir biçimde tiyatro olmadığı, tiyatro ve diğer alanları ile ilişkili bir alan olduğu vurgulanmalı, drama öğretmenlerinin amacinın gösteri amaçlı çalışmalar yapmak olmadığı belirtilmelidir. Drama öğretmenlerinin drama dersini yapılandırırken hem öğrenme -öğretme ilkelerinden hem de dramanın yapılandırma ilkeleri açısından yeterlikleri olmalıdır.

Bedene dayalı oyunlar ve materyal oyunları olarak verilmeye çalışılan oyun odaklı çalışmalar, "oyun ve drama ilişkisi" başlığı ile ünitede yer alabilir. Bu ünitede oyunun tanımı, kapsamı, sınıflandırılması ve drama ile ilişkisi üzerinde durulabilir ve oyun uygulamalarına yer verilebilir. "Rol Oyunları Alıştırmaları" ismiyle herhangi bir konu başlı̆̆g yer almamalıdır. Rol oynama ve doğaçlama, dramanın en önemli iki tekniği olduğu için "doğaçlama ve rol oynama” başlığıyla bu tekniklerin özelliklerinin ve canlandırma kurallarının da işlenmesi gerekir. Dramanın toplumsal boyutu, doğaçlama ve rol oynama, güven ve uyum başlıklarıyla ele alınması gereken ünitelerin de programa eklenmesi gerekmektedir. Yukarıda belirtildiği gibi bazı ünitelerin başlıkları yanlış ifade edilirken bazılarının da içeriği yanlış çalışmalarla eşleştirilmiştir. 
Drama dersinin öğrenme- öğretme süreci drama aşamalarına göre planlanmalıdır. Ancak programdaki üniteler, dramanın aşamaları dikkate alınarak planlanmamıştır. Tüm ünitelerin rol oynama ve doğaçlamaların kurgulandığı "canlandırma" aşamaları çok zayıf, hatta bazı ünitelerde bu aşama neredeyse yoktur. Bunların yanı sıra drama alanında ortak dilin yakalanması ve çalışmaların içeriğinin netleşmesi açısından etkinliklere veya oyunlara verilen isimlerin terim birliği içinde programda yer alması gerekmektedir.

\subsection{Temel Beceriler}

“5.2. Temel Beceriler” alt başlığı ile verilen beceriler; empati (duygudaşlık) kurma, bağımsız düşünebilme, beden dilini kullanma, drama tekniklerini kullanabilme, grup ile çalışma, imgelem (hayal) geliştirme ve ifade etme olarak gösterilmiştir. Programda yer verilen bu beceriler çok eksik olarak verilmiştir. Drama dersinde bu becerilere eklenecek pek çok beceri söz konusudur. Sözgelimi, iletişim becerisi, eleştirel düşünme, yaratıcılık, sosyalleşme, problem çözme, toplumsal empati vd. gibi. Programda bu becerilerin, içeriğinin gerektirdiği şekilde ve kazanımlara entegre edilerek verileceği vurgulanmaktadır. Empati becerisine tüm program boyunca bir kazanım olarak yer verilmiştir. Empati becerisi, sürece dayalı bir beceri olup tek kazanım ya da tek etkinlikle geliştirilebilecek bir beceri değildir. Bağımsız düşünebilme becerisine yönelik de bir kazanıma rastlanmamıştır. Zira etkinlik örneklerinde dramanın olmazsa olmazı olan bir çatışma-problem durumuna yer verilmemektedir. Aynı biçimde drama tekniklerini kullanabilme olarak verilen becerinin de ünitelerde yeterli oranda yer almadığ 1 görülür. Doğaçlama ve rol oynamadan bir iki etkinlik örneğinde söz edilmektedir. Bir kez donuk imgeye yer verilmektedir. Bunun dışında dramanın diğer tekniklerinin büyük bir kısmına yer verilmediği görülmektedir. İmgelem (hayal) geliştirme becerisinin de yalnızca son ünitede geliştirileceği üzerine yapılan plan eksiktir. İmgelem de tıpkı iletişim, yaratıcılık, empati gibi bir derste, bir etkinlikte gelişebilecek beceriler değildir. Bu beceriler süreç içerisinde gelişebilir. Bu nedenle tüm kazanımların bu tür becerilere uygun etkinliklerle gerçekleştirilmesi gerekir.

\subsection{Değerler}

“5.3. Değerler” alt başlığı ile Drama Dersi Programı “Dayanışma, Hoşgörü, Sevgi, Sayg1, Duyarlılık, Vatanseverlik, Barış, Estetik, Sorumluluk, Paylaşımcılık, Öz bilinç, Öz yönetim, Öz güven” olarak sıralanan değerleri kazandırmayı önemsemektedir. Ancak ünite, konu, kazanım ve etkinlik örneklerine bakıldığında bu değerlerin büyük bir çoğunluğuna ulaşılamayacağı görülür. Duyarlılık, vatanseverlik, barış, estetik, öz bilinç, öz yönetim ve öz güven gibi değerlere yönelik doğrudan kazanım ve etkinlik örneklerine rastlanmamaktadır.

\subsection{Drama Etkinlik Örnekleri}

Ünitelerden sonra programda yer alan "Drama Etkinlik Örneği 1 ve 2" olarak verilen örnek çalışmalar, drama dersinin yapılandırılmasına uymayan özelliklere sahiptir. Birinci örnekte, sürenin bir ders saati olduğu gözetilmeden fazlaca oyun etkinliğine yer verilmiştir. Oysa bu ünite başlığında verilen 6 kazanımın, 5 ders saati içerisinde verilmesi gerekirken örnek çalışmada dahi 40 dakikalık bir ders süresince bu kazanımlara ulaşılması beklenmektedir. Bu olanaklı değildir. Ayrıca etkinlik örneğindeki en önemli eksiklik, yapılandırma içerisinde canlandırma etkinliklerine yer verilmemesi, bir doğaçlama ya da rol oynama etkinliği içermemesidir. Müzik ve ritim odaklı çalışmalar oyun ve ısınma etkinlikleri olarak değerlendirilebilir. Ancak drama etkinlik örneği olarak verilen planın bir drama ders planı olmaktan uzak olduğu görülebilir.

İkinci drama etkinlik örneği de hemen hemen birinci örnek ile aynı eksikliklere sahiptir. Planlarda sadece oyunlar üzerinde durulmuş ve dramanın temeli olan canlandırma etkinliklerine yer verilmemiştir. Ayrıca tüm ünitenin 5 kazanımının da bir ders saatinde verilmiş görünmesi, eğitim programı açısından zaten uygun görünmemektedir. Ayrıca drama derslerinde değerlendirme aşamasıyla ilgili sözü edilen formların dışında herhangi bir etkinlik veya soru belirtilmemiş olması da bir diğer eksikliktir. 


\section{7. Ölçme ve Değerlendirme}

Drama Öğretim Programı'nda Ölçme ve Değerlendirme başlığı altında “...Drama öğrencinin duyuşsal gelişimini, bir alanda gösterdiği performansı ya da psiko-motor becerilerini ölçmek için öz değerlendirme, grup değerlendirme ve gözlem formları gibi ölçme yöntemleri daha uygundur. Drama çalışmalarında başarı ve başarısızlık kesinlikle bir değerlendirme ölçütü olmamalıdır. Sadece öğrenme ürünü değil, öğrenme süreci de değerlendirilmelidir..." (MEB, 2012, s.18) belirlemeleri yapılmaktadır. Drama dersi, programda belirtildiği gibi öğrencinin sadece duyuşsal ve psiko-motor becerilerini geliştirmez. Drama dersinde, öğrencilerin merkezde ve etkin olduğu, yaşantılara dayalı etkinlikler yer alır. Bu nedenle drama bilişsel, duyuşsal ve psikomotor gelişimlerin tamamında etkilidir ve tümel bir öğrenmeyi sağlar.

Programda değerlendirme ölçekleri olarak öz değerlendirme, grup değerlendirme ve gözlem formları gibi formlar önerilmektedir. Oysa drama gibi yaşantı odaklı olan bir ders için bu sayılanların dışında; günlük tutma, dereceli puanlama anahtarı (rubric), ürün dosyası (portfolyo), akran değerlendirme, bireysel değerlendirme, ürüne (mektup, öykü, anı, vb.) dayalı değerlendirme ve sözel değerlendirme gibi ölçme araçları da kullanılabilir. Zorunluluk olmamasına rağmen gerekli durumlarda dramanın temel kavramları, tarihçesi, öncüleri gibi diğer konular için yazılı sınavlar da yapılabilir. Dramanın aşamalarının her birinin ya da birkaçının ardından gerçekleştirilen ara değerlendirmelerde tartışmanın açılması, eleştiri-özeleştiri yapılması, soru-cevap gibi tekniklerin kullanılması da değerlendirme aşamasında söz konusu tekniklerin kullanılabileceğini göstermektedir.

Drama Öğretim Programı'nda ek olarak verilen formlar incelendiğinde, maddelerin yeniden değerlendirilmesi gerektiği ve formlarda drama yaşantılarına uygun ifadelere yer verilmesi gerektiği düşünülmektedir. Bir grup etkinliği olan dramada, öğrencilerin öncelikle kendilerini sonra da çalıştığ 1 grubu değerlendirmesi, çalışmaların amacına ulaşması için çok önemlidir. Öğretmen, öğrencilerin hem kendilerini hem başkalarını değerlendirmelerine yönelik bir yaklaşımı belirlemeli, hem de katılımcılarda olası ilerlemeyi ortaya çıkarabilecek bir ölçme bilgisine de sahip olmalıdır.

\section{Sonuç ve Öneriler}

Drama Dersi Öğretim Programı; program geliştirme ilkeleri, yer verilen kuramsal bilgiler, drama sürecinin yapılandırılması, program ögeleri (hedef, içerik, eğitim durumu ve değerlendirme) ve etkinlik örnekleri açısından incelenerek yukarda belirtilen bulgulara dayalı olarak eksik ve yetersiz bulunmuştur.

Program ögeleri açısından, programın önerdiği kazanımların büyük çoğunluğu, ders kazanımlarını karşılamaktan uzak olduğu düşünülmektedir. Programın kazanımları ile genel amaçlar arasında bağlantı zayıftır. Aynı biçimde kazanım ve etkinlikler ile beceri ve değerler arasındaki bağ da yeterince kurulamamıştır. Programda dramanın farklı kullanım biçimlerine ve yapılandırılmasına yeterince yer verilmemiştir. Programa göre kazanımlar için ayrılan süre yeterli değildir. Uygulama etkinlikleri ile bu kazanımlara ulaşılması olanaklı görülmemektedir. Belirtilen amaç ve becerilere uygun kazanımlar bulunmamakla birlikte, dramanın ara disiplinlere yönelik kazanımlarına da hiç yer verilmemiştir. Programda belirtilen kazanımların gerçekleştirilmesi, belirtilen etkinliklerle olanaklı görülmemektedir. Oyunun bileşenlerinin drama olarak verilmesi nedeniyle bu kazanımların drama olarak gerçekleştirilmesi olanaklı değildir. Programda önerilen drama tekniklerine ilişkin örnekler çok eksik ve yetersizdir. Bu bilgilendirme ve örneklerle drama tekniklerinin uygulanması zor görünmektedir. Programda belirtilen beceri ve değerlerin, verilen etkinlik örnekleri ile drama dersine ve öğrencilere yansıtılacağına ilişkin kuşkular bulunmaktadır.

Kuramsal bilgiler açısından, programda dramanın bir oyun olmadığı ve oyunun özelliklerinden tıpkı tiyatro gibi yararlandığ 1 üzerinde yeterince durulmamış, dramanın yer yer sadece oyun etkinliği yer yer de tiyatro gibi bir bileşene sahip olduğu yanılgısı üzerinde durulmuştur. Dramanın temel kavramları ve tekniklerine ilişkin hatalı ve eksik bilgiler bulunmaktadır. 
Programda drama eğitmeni/lideri ya da öğretmeninin sahip olması gereken yeterlik ve özellikler üzerinde durulmamıştır. Drama dersini yürütecek öğretmenlerin en az 320 ders saati olan bir eğitimden geçmesi drama dersini planlama, uygulama, değerlendirme yeterliğine sahip olacak bir donamıma sahip olmalarını sağlayabilir.

Program geliştirme ilkeleri açısından incelenen program, deneme çalışması yapılıp sonuçlar alınmadan yazılmış gibi bir izlenimi çağrıştırmaktadır. Program hazırlama sürecinde dramayla ilgili nitelikli kaynaklar yerine sınırlı sayıda, doğrudan dramayla ilgili olmayan kaynaklara ve çoğunlukla internet kaynaklarına başvurulduğu belirlenmiştir. Belirtilen eksiklerin ve yanlışların giderilerek programın tekrardan yapılandırılması uygun olacaktır. Ancak Drama Dersi Öğretim Programı bu haliyle ya uygulamadan kaldırılmalı ya da bu konu hakkında yaratıcı drama alanında lisansüstü eğitim programlarına sahip üniversitelerle (Ankara Üniversitesi, Anadolu Üniversitesi) işbirliği yapılarak yeni bir ders programı geliştirilmelidir. Programın geliştirilme sürecinde, drama alanı ile ilgili sivil toplum örgütleri de dahil olmak üzere tüm paydaşların olacağı bir program değerlendirme çalışmasının uygulama sonuçları da göz önünde bulundurulmalıdır.

\section{Kaynakça}

Adıgüzel, Ö. (2012) Eğitimde Yaratıı Drama (2.Baskı). Ankara: Pegem A Yayınları.

Erden, M. (1998). Eğitimde program değerlendirme. Ankara.

Nickel, H.W.(1976) “Spielpaedagogische Grundformen”. Spiel-Theater-,Interaktionspaedagogik, Hilfen für den Spielleiter, Heft 16, Recklinghausen.

MEB (1998) İlköğretim Okulları Seçmeli Drama Dersi 1-2-3 Öğretim Programı. Ankara.

MEB (2008) Drama Dersi Öğretim Programı. Ankara.

MEB(2012) Güzel Sanatlar ve Spor Liseleri Drama Dersi Öğretim Programı. Ankara.

Varış, F. (1976) Eğitimde Program Geliştirme. Ankara: Ankara Üniversitesi Eğitim Bilimleri Fakültesi Yayınları. 


\title{
Summary
}

\section{Assessment of Ministry of Education Fine Art and Sports High School Drama Lecture Teaching Program}

\author{
Doç. Dr. Ömer ADIGÜZEL ${ }^{1}$
}

\section{Introduction}

This study is aimed at assessing the teaching program of 2012 Ministry of Education Drama lecture in terms of the components of educational program such as objectives, content, learning conditions and assessment and the properties of creative drama field. To reach this aim, answers were searched to the following questions.

1. Is the preparation process of the program consistent with the principles of program development?

2. What is the appropriateness of information given under the heading "Drama" with the properties of field of drama?

3. How the drama lecture teaching program was constructed?

4. Are the components of drama lecture teaching program (objectives, content, learning conditions, assessment and evaluation activities) is compatible and consistent with the structure of the program?

\section{Method}

This study is a qualitative study in nature in terms its model. Documents of teaching program developed in relation to Drama lecture were searched and the data obtained was analyzed by document analysis. In this study, "Fine Arts and Sport High School Drama lecture Teaching Program" which was prepared by General Management of Ministry of Education and approved by Board of Education and Discipline with date 05.04.2012 and number 20 were assesed by considering teaching program components (purpose, content, principles, methods, techniques, instruments and teaching-learning process suggested in the program) in terms of relevance to creative drama field knowledge, purposes, properties and principles.

\section{Findings and Comment}

It was discussed about to what degree the program development princinciples were considered during the preparation of drama teaching program. At the end of the assessment related to this dimension of the program, it can be stated that drama lecture teaching program has various problems in terms of program development principles. Fine Arts and Sport High School Drama lecture program was seen as prepared and put into practice in 2012. However, the program which is valid now was constructed with the modified form of Anatolian Fine Arts High School Drama lecture program which was applied in 6 years approved by Board of Education and Discipline with the date 08.12.2006 and number 392. With this perspective, 2012 Drama teaching program was published without carrying out any program development and assessment studies by correcting the errors and deficiencies of the previous program and it is observed that the program was approved by changing the name of the program and it is in form of the continuation of the former program.

Under the heading of "Basic Components" the components given for drama was not reflected correctly in the program. As understood from translation text of the original name, the components given as basic compo-

1 Doç. Dr.Ankara Üniversitesi Eğitim Bilimleri Fakültesi. omeradiguzel@gmail.com 
nents of drama are actually the basic forms of "Play and Play Pedagogy". In the original form of the text, the components are not given for drama but given as different fields-forms of the plays. When it is looked at the title of the unites, it is seen that content is made largely with topics and activities suitable fort he tool dimension of drama other than the purpose dimension. The dominant fields of the program consist of group dynamic, rythm, voice, movement, play, warm-up activities, plays based on body, material plays and it is seen that plays constitute the wide range of the program. It is unthinkable for improvisation and role playing is included in only one unit under the heading "role playing" as role playing is prerequisite of drama.

In drama lecture, activities in which the students are in the center and experiences are the focus of the activities. Therefore, drama leads to universal learning. Besides these assessment techniques, as drama is a lecture based on life experiences, keeping diaries, grading scales, rubrics, portfolios, peer assessments, individual assessment, assessment based on product and verbal assessment might be used.

Drama lecture program was assesed and examined by considering the purpose, content, principles, construction, components of educational program, examples of applications, units and examples of activities methods of creative drama field and Important deficiencies and errors were detected in the program. Majority of the Objectives in program are not satisfying the objectives of the lectures. In the same manner, also the connection between the skills and values of the objectives and activities is weak.

Therefore drama lecture teaching program should not applied in this version and it must be cancelled or a new lesson program should be developed with a collaboration with Ankara University and Anadolu University where postgraduate education programsa re being applied. Teachers should get 320 hours drama lectures for conducting a drama lesson and by this way it might be possible to have equipped with the qualification for planning, applying and assessing the activities. 